Image and Man - Correlations, eds. Marcin Godawa, Bojan Žalec, Krakow 2020, pp. 21-33.

DOI: http://dx.doi.org/10.15633/9788374386807.03

Magdalena Ficoń

The Pontifical University of John Paul II in Krakow, Poland

\title{
A Visualisation of Some Biblical Passion Verses in the Emblems Placed at the Cloisters of the Monastery of the Franciscan Friars in Cracow
}

The allegorical way of thinking was characteristic of people of the Renaissance. Common belief had it that that any given thing could be expressed with the use of signs, words, coats of arms, slogans or emblems and that any concept, even the most abstract, could be expressed with an image. The above-mentioned way of thinking was not new. The new thing of that century was a predilection for allegories and emblems and for juxtaposing concepts with images. This was the reason why a group of people dedicated themselves to the task of devising emblems and allegories. They pursued that task systematically, in two main fields: emblematics and iconology (Tatarkiewicz 1991, 211).

What is emblematics? In the first place, it is art, because - as a Latin apothegm has it - ars est quae dat rationes certas, which means that art is what is based on reliable rules. Emblematics indeed made use of fixed allegories, drew upon the relation between words and images, abode by general rules and avoided discretion. People who lived at that time perceived emblems as a genre that was something between poetry and painting, or poetry and visual arts. Mainly the fact that emblematics employed some general rules and principles contributed to its perception as a system of repeatable, definite and generally understood painted and written symbols (Tatarkiewicz 1991, 214). Emblematics is an art genre that employs both 
words and pictures. This is why it has been arousing the interest of both art historians and literary scholars. Words and pictures are combined in a conscious way to help individuals learn and understand the world around them as well as plumb its mysteries and mechanisms. In order to understand emblems in a proper way, one has to draw on different scholarly disciplines, such as theology, history and cultural studies (Pelc 2002, 9; Rotter 2007, 81; Lurker 1994, 99).

It is impossible for things to emerge from nowhere, so it is clear that emblematics has not sprung up in a vacuum. It has early Christian and medieval roots. It also borrows from ancient patterns, as it was in ancient Egypt where combinations of words and pictures were used. The creators of the modern emblematics considered Egyptian hieroglyphics to be the first form of conveying one's thoughts by means of symbols and saw it as a prototype of emblems. In Hellenic, Hellenistic and Roman cultures, artists carved sculptures of gods and people, and decorated them with apothegms and poems to explain their meaning. The task of those maxims consisting of words was to express the meaning of visual shapes and colours of the works. Not only were maxims and poems carved out on sculptures, but they were also incised on low reliefs that covered outside and inside walls of Roman architecture. The tradition that started in pagan Rome was adopted by Christian Rome. In times of persecution and meetings in the catacombs, Christianity created its own symbolism that drew on the Old and New Testaments. The symbolism combined Hebraic and Egyptian traditions with Greek and Roman ones (Pelc 2002, 15; Rotter 2007, 81; Rotter 2004, 99-103; Buchwald-Pelcowa 1981, 9; Tatarkiewicz 1991, 212).

The ancient tradition of decorating works of art with inscriptions had survived into medieval times, and it might be said that it was even more popular in that period. Artists used inscriptions to explain the allegorical meaning of the visual side of their works, and the visual side pointed out to the inscriptions. One had to be able to read in order to understand the inscription, which was not so common in early medieval times, and image, however to a different extent, always had influence on its observers.

Medieval emblematics is considered to have originated in heraldry, where a knight's coat of arms was usually accompanied with a short maxim. The maxim consisted of two parts and was called a motto. Early humanists understood a motto as a maxim combined with a symbol or visual 
representation (Pelc 2002, 16-17). This combination can be considered a pre-emblematic concept. ${ }^{1}$

Andreas Alciatus is considered to be the originator of emblematics, and 1531 is considered to be the year in which this branch of arts came into being. This was the year when Alciatus' work Emblematum liber was publicised (Buchwald-Pelcowa 1981, 8). Alciatus described an emblem as consisting of three parts: inscription (also known as "motto"), image and subscription (or epigram). In his work Poetics published at the end of the $16^{\text {th }}$ century, Jesuit Jacob Pontanus ${ }^{2}$ gave his definition of an emblem and the parts of which it should consist. The tripartite composition of the work of art was clearly specified. ${ }^{3}$ The inscription was shown as an emblem's soul (anima), the image - as its body (corpus), and the subscription its mind (animus) (Pelc 2004, 179). The epigraph-motto and the image were two works, but they interpreted each other and thanks to this they comprised a unitary organism that combined soul and body, and this is the reason why two-part emblems were most common. The subscription was omitted.

Two basic categories can be distinguished in the seventeenth- and eighteenth-century emblematics: secular and religious emblems. Secular emblematics included works coming from bourgeois and folk circles. Such emblems were created on the occasion of weddings and funerals. Political and erotic emblems were also produced. The second category included emblems showing Marian, mystical and hagiographical contents, and in Protestant circles - biblical ones. What the aforementioned categories have in common is a thematic group comprising emblems that present moralistic and didactic contents addressed to all social groups. Moralistic and didactic emblems show a righteous man, regardless of his social group or function, but they also point out vices by contrasting them with right and righteous attitudes (Rotter 2007, 85-86).

1 Over time, the terms „motto," "maxim” and "lemma” were used interchangeably. A two-part motto was also referred to as an "impresa," the word which was later used by Italians in reference to an emblem. Cf. Pelc 2002, 17; Tatarkiewicz 1991, 211-212.

2 Giving his definition of an emblem, Jacob Pontanus referred to Paulo Giovio's concept of a two-part motto (Dialogo dell'Imprese Militari et Amorose, 1555) that consisted of an image-body (corpora) and an inscription-soul (anima). Cf. Pelc 2004, 178.

3 As mentioned above, a classical emblem is a tripartite composition, however, simpler two-part compositions called "emblemata nuda" were popular in Europe. In this case, images were replaced with descriptions. Cf. Pelc 2002, 39. 
It is also worth mentioning iconology which has been considered a twin discipline of emblematics. Similarly, iconology can be considered an art of combining words and images. The difference between them both is that the task of emblematics was to match signs to specific people and general concepts, whereas the task of iconology was to match them only to concepts. Iconology emerged when emblematics had fully developed. Similarly to emblematics, iconology drew on Egyptian, Greek and Roman sources. It was initiated in 1593 by Cesare Ripa when he published his work Iconologia that became a "reference book" for poets, speakers and artists who wanted to express abstract concepts, virtues and feelings in a pictorial way (Pelc 2002, 47-49; Pelc 2004, 180-182; Rotter 2007, 84; Ripa 1998).

Not only were emblems present in literature and books, but they also would be elements that adorned buildings, objects, gardens, decorations connected with occasional festivities and spectacles. One can ask why it was this branch of art that was so popular. The answer is that this way of symbolic depicting gained recognition and popularity because of the mysterious and enigmatic character of the contents as baroque artists wanted to astonish their audience. Emblems were ideal tools to achieve this objective. Unravelling the message behind an emblem was excellent intellectual entertainment. When looking at the inscription and image, one had an opportunity to decipher the meaning of the depiction, and then verify his or her interpretation. In this respect, unravelling the meaning of emblems was considered entertainment for intellectuals, or people who had knowledge and broad mental horizons as this task demanded knowledge of history, politics, theology, hagiography, spirituality, etc. (Pelc 2002, 119-121; Rotter 2007, 85).

The cloisters of the Franciscan monastery in Cracow are one of the places where emblems can be found. In the south-eastern span, there is a baroque polychrome dated back to the second half of the $17^{\text {th }}$ century. It includes seven emblems in decorative cartouche frames related to the words of Jesus Christ on the cross and six scenes illustrating the course of events during the Passion and after Christ's death (Bochnak, Samek 1971, 121). Contemplation of those thirteen images arranged in one series lets one experience and visualize by means of words and images the contents read during the liturgy of Good Friday.

In the first emblem, its author depicted in a way that was contemporary to him, as the attire of the figures shows, the capture of Jesus and bringing him to appear before the high priest (Picture 1). In the picture, there is a Roman 
tribune who is holding a banner with the abbreviation SPQR which means Senatus Populusque Romanus. In ancient times, the formula was an official name of the Roman Empire that symbolized the senate and the people as the legislative branch. The tribune is accompanied by a cohord and Jewish servants holding handles in their hands. Captured Jesus can be seen between the cohord and the tribune; the high priest holding a sword can be seen on the left. The sword is usually used by people to fight or defend themselves, also as part of the execution of judicial power. The use of the sword as a weapon can be also considered as the use of a kind of a spiritual sword. Bad words bring misfortune and the words of God bring salvation. That is why the symbolism of the sword can be related to the trial of Jesus and the witnesses' false statements (Forstner 1990, 467). The painting is accompanied with the words Pater ignosce eis quia nesciunt quid faciunt which mean Father forgive them, because they do not know what they are doing. These are the first words that were said by Jesus on the cross. He defends his enemies, forgives the ones contributing to his death and prays for them. Why? Because he himself, at one time, told to pray for the enemies and revealed his followers the words of the prayer "And forgive us our trespasses, and we forgive those who trespass against us" (Zaleski 1964, 457).

Another emblem is impenetrable for art historians. Any attempt of interpretation is hindered by the lack of a motto under it. It is probably because of the fact that it may have not been added or retained. In a semantic point of view and in the context of the whole series, this emblem is related to the second part of the words Jesus said on the cross: Truly, I say to you, today you will be with me in paradise. The words can be only read in the Gospel of Luke and they are dedicated to a converted villain who, facing death, asked for the grace to be in the Kingdom of Heaven (Zaleski 1964, 459-460). In this picture, a church can be seen (Picture 2). Thus, when interpreting its meaning, one should refer to the symbolism of a Christian sanctuary. The sanctuary stands for the Body of Christ. The symbolism that is totally independent of the form of the cross on which the plan of the building is based was accurately emphasized by this architectural form. If one wants to enter the church, the door which symbolizes Jesus Christ should be trespassed. Entering the church and crossing the door means the secret of 'entering' the gateway into the spiritual world. We should realize that we cross the Heaven's door every time we go to church. As Jesus said: I am the gate; whoever enters through me will be saved (John 10:4). This is the reason why 
these words of Jesus on the cross were depicted by means of the image of a church building. Jesus promised the villain who believed in him that he would cross the door to the Kingdom of Heaven.

Next, Maria and Jesus' beloved disciple can be seen (Picture 3 ). There is a sentence: Mater ecce filius Tuus which means Mother, this is your son. And this is the third of the sentences that Jesus said. The scene is depicted in some unusual way, that means there is no cross that could be seen, instead, we can see some calm scenery, a blue sky and some trees in the distance. There are no signs of agony or suffering. Maria is wearing a blue coat and a red gown under it. Blue is the symbol of irreproachability and purity, these are the attributes of the Heaven. That is why the blue colour is associated with the Mother of God. The red colour is the symbol of martyrdom, blood, love and motherhood. The red gown of Maria emphasizes her royal dignity as the Mother of God. The hands that are pointed to the disciple are also worth taking into consideration. The disciple is depicted with his hands folded, which symbolizes his dependence on someone who is "above" him as well as his dedication. The man's blue robe is the symbol of stability, constancy and faithfulness, whereas the red coat symbolizes strength and youth (Forstner 1990, 20, 116-120). The author of the painting shows, in a calm and subtle way, the birth of the Church, which is fulfilled in the Mother of God and Jesus' beloved disciple. The unity of the messianic people of God, or the New Israel, is the fulfilment of it.

The next words of Jesus Ut quid dereliquisti me, which means Why have you abandoned me?, are associated by the author with a boat. In the picture, a solitude boat is drifting on the rough sea. In the background, the sky is dark and cloudy (Picture 4). In the Holy Bible, the image of the sea is considered as some kind of danger, chaos and death. The boat is seen as the safety that God gives his people who are endangered by the evil that surrounds them (Ryken, Wilhoit, Longman III 2003, 476-477). One of the interpretations of the boat symbol is that the boat stands for crucified Jesus. To build a ship one needs three different kinds of wood. Similarly, many exegetes mention the "triple" wood of the cross. There is no chance to cross the sea without sailing on a wooden, nailed ship and there is no chance to overcome the world's evil without the sacrifice of Jesus ${ }^{4}$ (Lurker 1989, 155).

4 A ship is one of the most meaningful symbols and stands for the return of the Church and souls to the Kingdom of Heaven. The Church Fathers often used this comparison, e.g. 
Going forward, we can see a painting which is calm and gentle. There is a deer in the bosom of nature, drinking some water from a lake/stream (Picture 5). The deer is the symbol of Jesus Christ. According to the ancient naturalists, it is possible for a deer to trail a snake in its hiding place, then to chase it out and kill by the use of its breath. In this context, the famous Physiologus teaches that a deer that defeats a snake can be compared to the Saviour who caused the serious dragon, Satan, die by the use of water from Heaven, that means the salutary doctrine (Lurker 1989, 77-78). The word Sitio, which means I desire, is part of the picture. The author uses the image of the deer drinking from the spring to express the will of Jesus to make people come to him as the source of the living water (an allusion to Psalm 42:2). The deer's antlers are also meaningful which stand for light. The symbolism is connected with the image of a winner, saviour and defender, which applies perfectly for Jesus who redeemed his people and defeated evil.

Another emblem depicts three figures who are hanging on the cross (Picture 6). In comparison to the last painting, the background is dark, gloomy and unpleasantly dangerous. In the distance, we can see an eclipsed sun. The inscription Consumatum est, that means It is completed can be seen as a part of it. The death of Jesus is shown by the author with no allegories and in the simplest way. The words It is completed mean that all of the prophecies have been fulfilled.

Another emblem is not so clear. Unfortunately, it has not been renovated to the end. It depicts God the Father who can be seen on a cloud (Picture 7). The cloud symbolizes God's presence as well as the fact that he is hidden. Clouds can be often considered as an image of the majesty of the Christ the King (Lurker 1989, 141-142; Ryken, Wilhoit, Longman III 2003, 615-616; Forstner 1990, 105-107). While looking at the painting and reading the sentence In manus Tuas ceommendo spiritum Meum, which mean Into your

\footnotetext{
Pseudo-Ambrose writes: The Church can be compared with a ship that sails upon the waters of the world. The ship is endangered by the wind, or temptations, and by whipped-up waves, or the powers of this world, that seek to hurl it on the rocks. Notwithstanding the waves, the ship will never suffer founder, because before the mast, which is the cross, Christ stands erect, at the stern the Father and the Holy Spirit, the Comforter, is its steersman [...]. St Hippolyte closes the apostolic tradition by describing the following image of a ship: My dear, if we oversee something, God will disclose it to those who deserve it, for He rules the Holy Church and directs it so that it could reach the harbour of peace. Cf. Forstner 1990, 426.
} 
hands, O Lord, I commend my spirit, we can have the impression that God the Father is holding his hands and waiting for his Son's coming back.

After those events there were signs in the Heavens and on the Earth. Jesus' enemies had demanded such signs many times, but they turned out to be ineffective in their eyes. First, the Sun was obscured - Sol obscuratum est. There is an emblem depicting a menorah with a cross that is emerging from it (Picture 8). In the Holy Bible, the menorah is a seven-branched candelabrum that can be seen in the Tabernacle and then at the Salomon's temple. The holy place of the saints, where the Ark of the Covenant, or God's Palace on the earth, was placed, was covered with a curtain. The continually glowing menorah was placed in front of the curtain, on the southern side. The fabric and shape of the menorah symbolized God's perfection, splendour and holiness. The cross from the menorah that symbolizes Jesus is the sign that no light will be needed anymore because of the presence of Jesus Christ himself who is the true light.

Following the darkness, the death of Messiah, the God impersonated, was announced by some unusual phenomena. The temple curtain was torn in two, or Velum templi scissum est. On the emblem, we can see the interior of the temple and a dark curtain which is tearing apart (Picture 9). There were three curtains in the temple: one of them was at the bronze door of the temple, another one separated the temple form the porch, and the third one separated the holy place from the holy place of the saints. One of the curtains has been torn, which symbolizes the end of the Old Covenant, as well as the beginning of the New one. The Old Testament sacrifices ceased to exist as soon as the Son had sacrificed himself.

After that Petrae scissae sunt which means the rocks were rent. It can be seen on the dark emblem depicting some high rocks that are cracking (Picture 10). The symbolism of the rocks and stones is very rich. In this case, it can be compared to stones used to close tombs. An attempt to interpret this painting in this way can be combined with the two other emblems depicting the further fragment of the Gospel of Matthew: The tombs broke open. The bodies of many holy people who had died were raised to life. They came out of the tombs after Jesus' resurrection and went into the holy city and appeared to many people (Matthew 27:50-53).

The first of the emblems is decorated with the inscription: Monumenta apperta sun. In the emblem, we can see a calm background and some trees in the distance. In the foreground, there are some figures coming out from 
the tombs (Picture 11). In the second emblem, we can see a town with its gates and some people crossing it (Picture 12). There is no inscription to it. Probably, it had faded away, so that it was not possible to renovate it, or it had not been placed there, similarly to the one of another painting. The Resurrection of the dead and their coming to the holy city is the sign of the eschatological era. People that have been set free from hell, come into the holy city of Jerusalem. This is one of the first expressions of faith in letting the dead people free by Jesus' descending into hell (Zaleski 1964, 462-465).

The last emblem of the series depicts the paschal lamb (Picture 13) that stands for Christ the Resurrected King. Jesus was named God's suffering servant by St John the Baptist, which means that he is the true paschal lamb. He said: Behold, the Lamb of God who takes away the sins of the world! Jesus died at the time when lambs were being killed in the temple in preparation for the paschal supper. It was forbidden to break the bones of a paschal animal, that is why the bones of Jesus Christ on the cross were not broken. St Paul says: For Christ, our Passover lamb has been sacrificed for us, whereas St Peter explains: It was the precious blood of Christ, the sinless, spotless lamb of God by which people were redeemed (Lurker 1989, 21-23).

Humans are sensuous and spiritual beings. For this reason they need symbols in order to introduce the spiritual aspects of life. It can be often seen that analyzing and feeling their rich contents means more than words. Different things are unified by the use of symbols, whereas the speech can make people aware only in a gradual and fragmentary way of what symbols depict to human souls.

The above-mentioned analysis was to prove that an image which is a symbolic sign can stand for deeper, hidden meanings. Not only with the use of words but also with the use of images, one can express the rights and truths of the world. Therefore, emblematic pieces of art should be taken into consideration in order to see, by means of pictures, the contents that cannot be expressed by words.

\section{REFERENCES}

Bochnak A. (red.), Samek J. (oprac.) (1971), Miasto Kraków, cz. 2: Kościoły i klasztory Sródmieścia, Warszawa (Katalog Zabytków Sztuki w Polsce, t. 4). 
Buchwald-Pelcowa P. (1981), Emblematy w drukach polskich i Polski dotyczacych XVIXVIII wieku. Bibliografia, Wrocław.

Forstner D. (1990), Świat symboliki chrześcijańskiej, Warszawa.

Hani J. (1994), Symbolika świątyni chrześcijańskiej, Kraków.

Lurker M. (1994), Przesłanie symboli w mitach, kulturach i religiach, Kraków.

Lurker M. (1989), Słownik obrazów i symboli biblijnych, Poznań.

Pelc J. (2004), Barok epoka przeciwieństw, Kraków.

Pelc J. (2002), Słowo i obraz na pograniczu literatury i sztuk plastycznych, Kraków.

Ripa C. (1998), Ikonologia, Kraków.

Rotter L. (2004), Duchowość i historia benedyktynek w symbolice malarskiej kościoła w Staniątkach, Kraków.

Rotter L. (2007), Emblematy jako wyraz postaw etyczno-moralnych. Zarys problematyki, in: Cnoty i wady. Społeczeństwo baroku po obu stronach Karpat, red. J. Marecki, L. Rotter, Kraków, pp. 81-103.

Ryken L., Wilhoit J. C., Longman III T. (2003), Słownik symboliki biblijnej, Warszawa. Tatarkiewicz W. (1991), Historia estetyki, t. 3: Estetyka nowożytna, Warszawa. Zaleski W. (1964), Zagadnienia biblijne. Jezus Chrystus, Poznań.

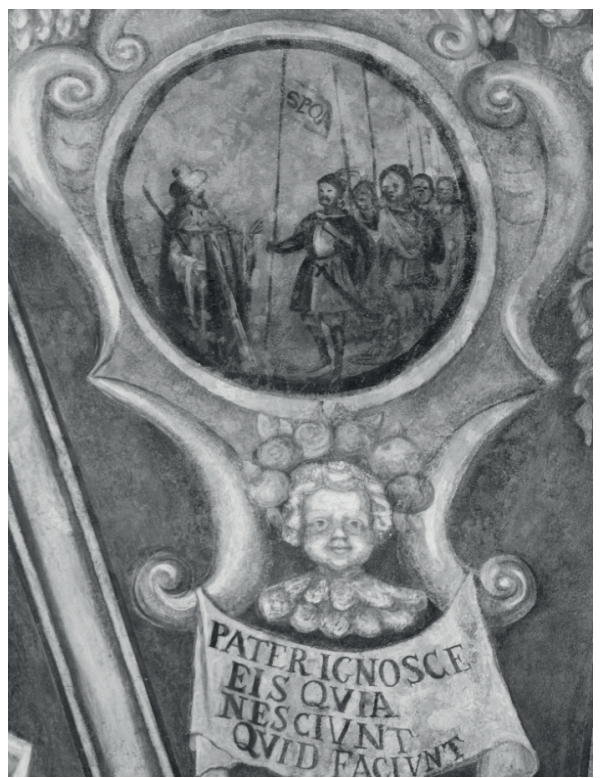

PICTURE 1

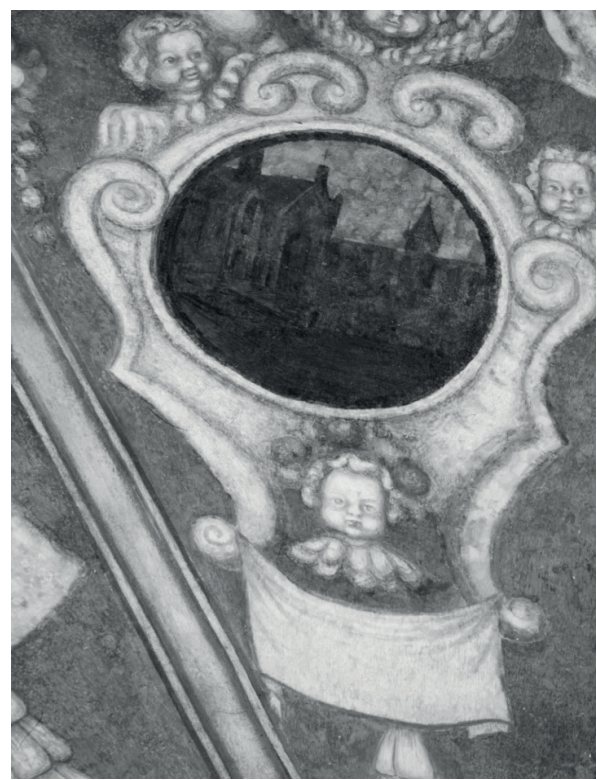

PICTURE 2 


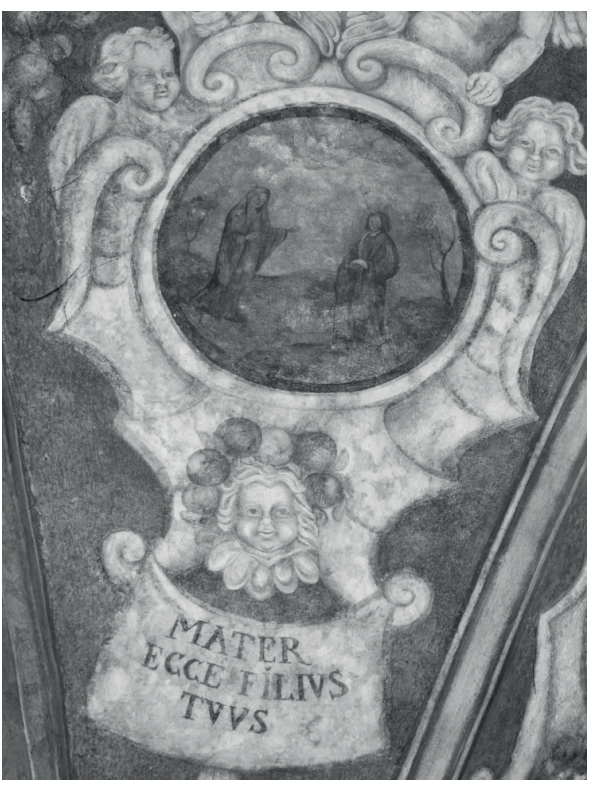

PICTURE 3

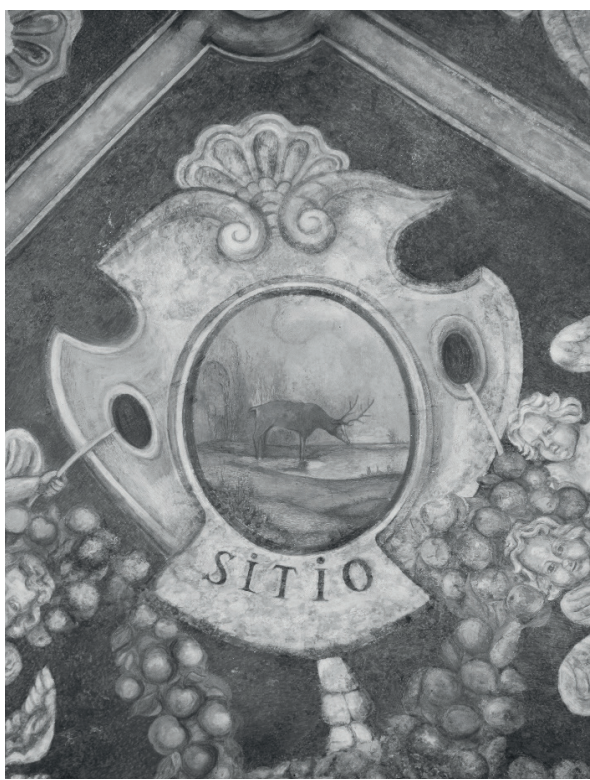

PICTURE 5

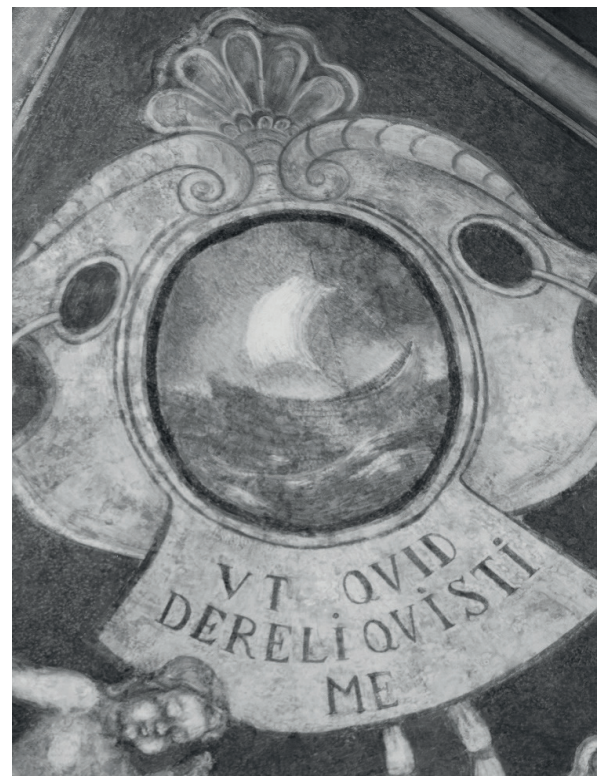

PICTURE 4

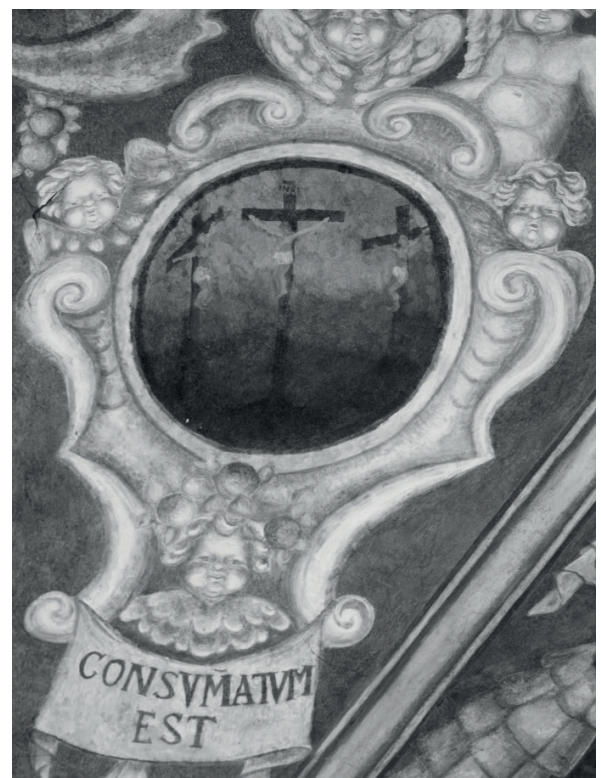

PICTURE 6 


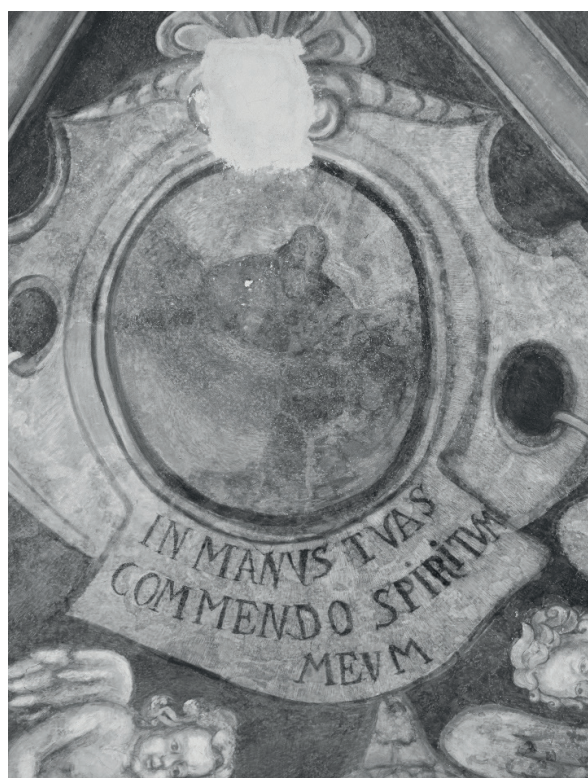

PICTURE 7

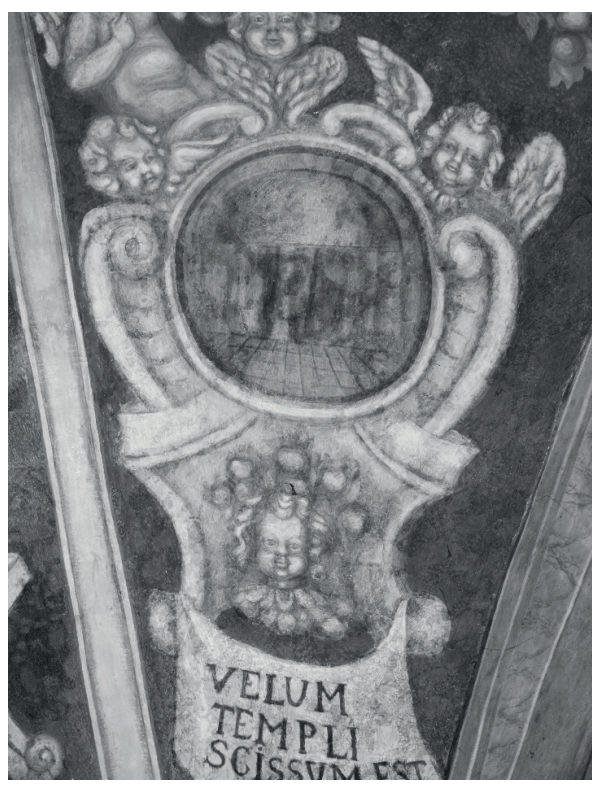

PICTURE 9

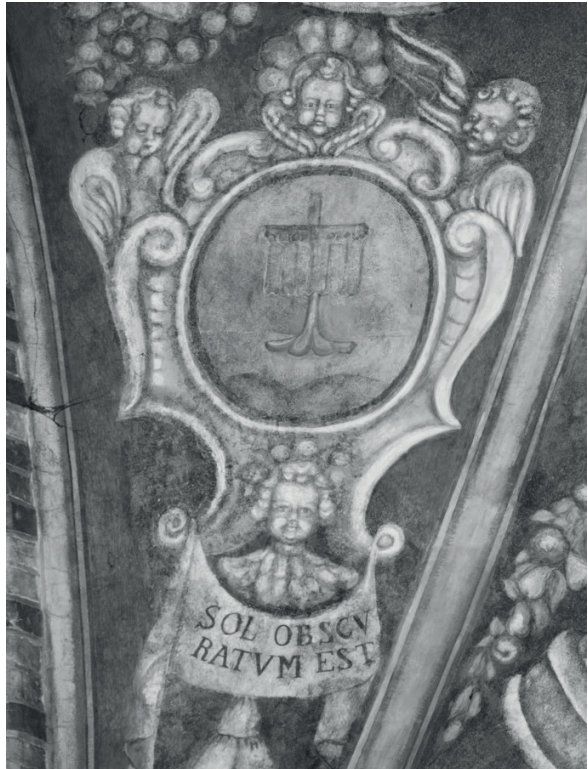

PICTURE 8

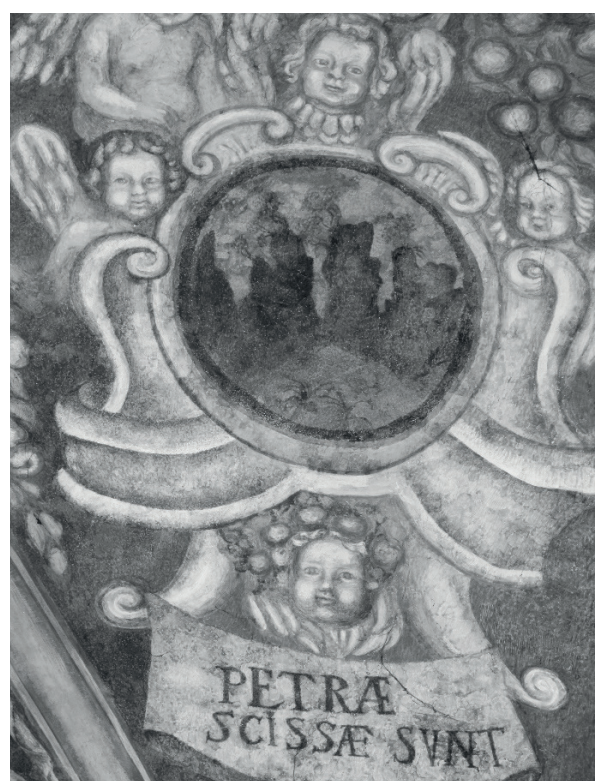

PICTURE 10 


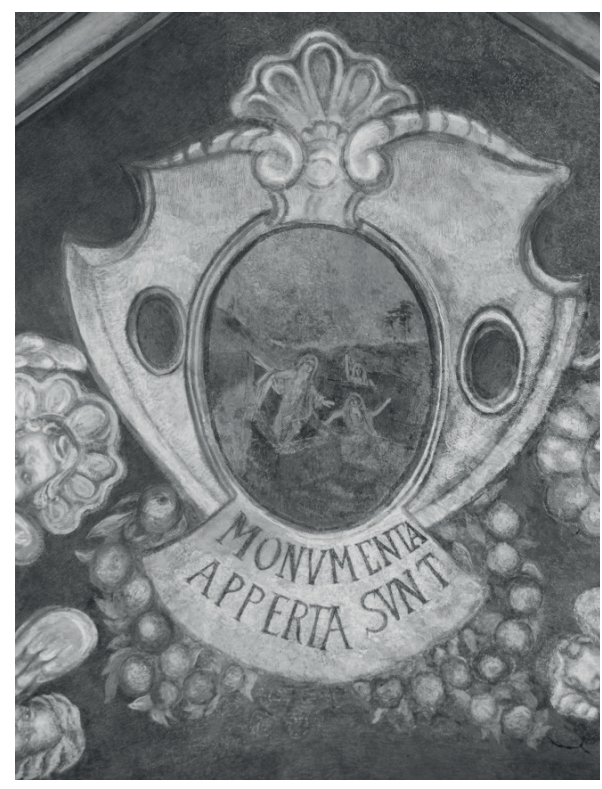

PICTURE 11

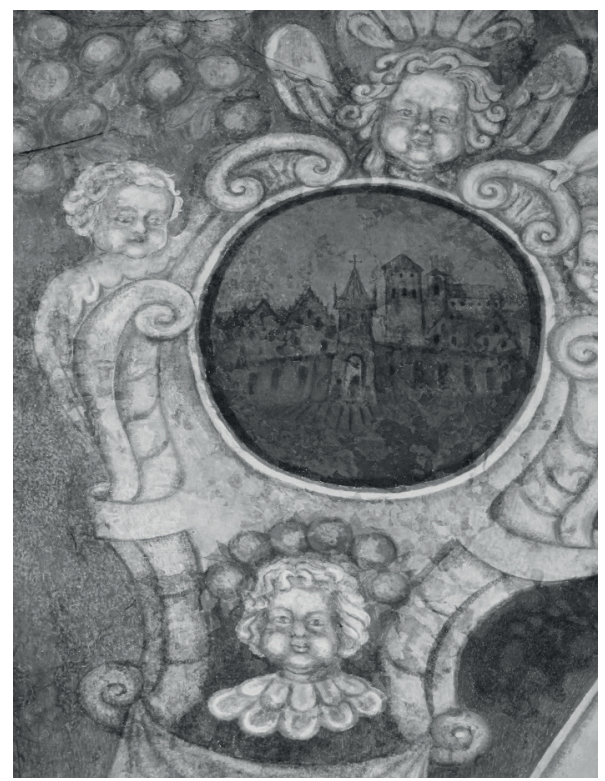

PICTURE 12

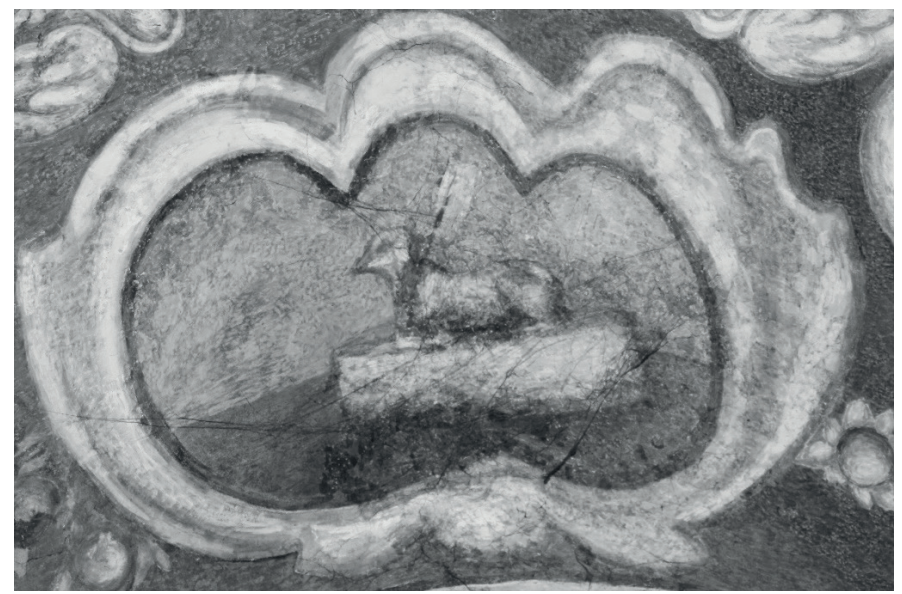

PICTURE 13 
